\title{
Surgical Treatment for Refractory Aggression after Bacterial Meningitis Complicated by Stroke: Case Report
}

\section{Tratamento cirúrgico para agressividade refratária pós-meningite bacteriana complicada por acidente vascular encefálico: Relato de caso}

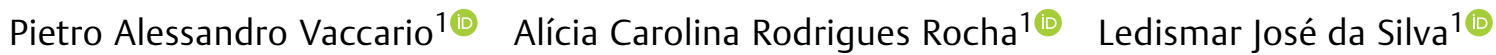 \\ ${ }^{1}$ School of Medicine, Pontifícia Universidade Católica de Goiás, \\ Goiânia, GO, Brazil \\ Arq Bras Neurocir 2022;41(2):e198-e206. \\ Address for correspondence Ledismar José da Silva, MSc, School of \\ Medicine, Pontifícia Universidade Católica de Goiás (PUC-Goiás), \\ Avenida Universitária, 1440, Setor Universitário, 74605-010, Goiânia, \\ GO, Brazil (e-mail: ledismarsilva@gmail.com).
}

\begin{abstract}
Keywords

- bacterial meningitis

- psychosurgery

- neurosurgery for psychiatric disorders

- limbic system

- aggression

\section{Resumo}

Palavras-chave

- meningite bacteriana

- psicocirurgia

- neurocirurgia para doenças psiquiátricas

- sistema límbico

- agressão
\end{abstract}

Bacterial meningitis remains a public health problem. One of the complications of this group of diseases is cerebral ischemia, an important indicator of severity and an independent predictor of poor prognosis. It is already known that, in many cases, pathological aggressiveness is the result of brain abnormalities in individuals with mental illnesses. The indication of neurosurgeries for psychiatric disorders (NPDs) relies on numerous studies based on scientific evidence that correlate psychiatric illnesses with the limbic system and the pathophysiology of emotions. The development of sophisticated stereotactic target localization techniques, brain atlases, and imaging methods made stereotaxis possible, a procedure that increased the precision of neurosurgery and reduced brain damage. Nowadays, multiple targets can be treated during NPD, according to the particular characteristics of the patient. Moreover, the combination of lesions leads to more significant improvements compared with isolated procedures. The present study aimed to report the rare case of a patient with a history of bacterial meningitis who developed stroke and chronic pathological aggressiveness refractory to clinical treatment and underwent ablation using the multitarget stereotactic technique.

A meningite bacteriana continua sendo um problema de saúde pública. Uma das complicações deste grupo de doenças é a isquemia cerebral, um importante indicador de gravidade e um preditor independente de mau prognóstico. Já se sabe que, em muitos casos, a agressividade patológica é o resultado de anormalidades cerebrais em indivíduos com doença mental. A indicação das neurocirurgias para doenças psiquiátricas (NDPs) se fundamenta em inúmeros estudos com base em evidências científicas, os quais correlacionam as enfermidades psiquiátricas com o sistema límbico e a fisiopatologia das emoções. O desenvolvimento de técnicas sofisticadas de localização received

October 27, 2020

accepted

September 6, 2021

published online

January 7, 2022
DOI https://doi.org/ $10.1055 / \mathrm{s}-0041-1740619$ ISSN $0103-5355$.

\footnotetext{
(c) 2022. Sociedade Brasileira de Neurocirurgia. All rights reserved. This is an open access article published by Thieme under the terms of the Creative Commons Attribution-NonDerivative-NonCommercial-License, permitting copying and reproduction so long as the original work is given appropriate credit. Contents may not be used for commercial purposes, or adapted, remixed, transformed or built upon. (https://creativecommons.org/ licenses/by-nc-nd/4.0/)

Thieme Revinter Publicações Ltda., Rua do Matoso 170, Rio de Janeiro, RJ, CEP 20270-135, Brazil
} 
de alvos estereotáxicos, atlas cerebrais e métodos de imagem tornaram a estereotaxia possível, um procedimento que aumentou a precisão da neurocirurgia e reduziu os danos cerebrais. Atualmente, múltiplos alvos podem ser tratados durante a NDP, de acordo com as características individuais do paciente. Ademais, a combinação das lesões leva a melhorias mais significativas em comparação com os procedimentos isolados. O presente estudo teve como objetivo relatar o caso raro de uma paciente com histórico de meningite bacteriana que evoluiu para acidente vascular encefálico e agressividade patológica crônica refratária ao tratamento clínico e foi submetida a ablação utilizando a técnica estereotáxica de múltiplos alvos.

\section{Introduction}

Bacterial meningitis remains a public health problem, ${ }^{1}$ and in 2019, 2,330 cases were confirmed in Brazil. ${ }^{2}$ One of the complications of this group of diseases is cerebral ischemia, an important indicator of severity and an independent predictor of poor prognosis. ${ }^{3}$ Among the main repercussions of bacterial meningitis are hearing loss, language disorders, mental retardation, motor abnormalities, and visual disturbances. ${ }^{4}$ Although no articles describing the evolution from bacterial meningitis to aggressive pathological behavior have been found, it is already known that, in many cases, pathological aggressiveness is the result of brain abnormalities in individuals with mental illnesses. ${ }^{5}$

The normal aggressive behavior in the human species aims to maintain the physical integrity, subsistence, territory establishment/maintenance of the individual, and perpetuation of the species. ${ }^{5,6}$ Aggressiveness becomes pathological when its manifestation becomes exaggerated in response to a stimulus that would normally not cause danger or even in the absence of a stimulus. ${ }^{7}$ Unfortunately, for patients with affective disorders resistant to treatment and their families, pathological aggressiveness represents an extreme emotional and psychological burden, in addition to an increased risk of suicide. ${ }^{8}$

Among the brain nuclei used as targets in stereotactic neurosurgeries for psychiatric disorders (NPDs) to control pathological aggressiveness, the following are considered the most important ones: the amygdala, the posteromedial hypothalamus, the ventral part of the internal capsule and the striatum, the cingulate, the substance innominate, and the nucleus accumbens (NAcc). ${ }^{9}$ These multiple targets can be used during the procedures according to the individual characteristics of the patient and to the experience of the neurosurgeon. Also, the combination of lesions leads to more significant improvement compared with isolated procedures. ${ }^{10}$ Therefore, the present study aimed to report the rare case of a patient with a history of bacterial meningitis who developed stroke and chronic pathological aggressiveness refractory to clinical treatment and underwent ablation using the multitarget stereotactic technique.

\section{Case Report}

The legal guardian of a 30-year-old female, with a pathological history of acute bacterial meningitis, previously healthy and with no comorbidities until she developed ischemic stroke at 15 years old, looked for medical assistance in 2019 because of her aggressive behavior. After the diagnosis of bacterial meningitis and the appropriate treatment, the patient presented with dysarthria, left upper limb hemiparesis with loss of movement at light touch, mental retardation, episodes of pathological aggressive behavior manifested as verbal aggression (screaming with anger, temper tantrums), property damage (slamming doors, throwing objects on the floor), self- injury (hitting herself and hitting her fists on the wall), and hetero-aggression (making threatening gestures, hitting and pushing others, even causing minor injuries). She scored 47 points on the Modified Overt Aggression Scale (MOAS) ${ }^{11}$ and also presented with intense sexual impulse, motor tic (clapping), vocal tic (recurrent sounds), and binge eating disorder.

The legal guardian claimed to have made use of grills and restraints on household utensils and objects to protect the patient, belongings, and property. Additionally, the family had to adopt social distancing due to embarrassment, conflicts, and compromised coexistence.

The magnetic resonance imaging (MRI) performed in 2019 (-Figs. 1 and 2), prior to the stereotactic NPD to control aggressiveness, shows most of the following injuries caused by the evolution of the bacterial meningitis and the stroke: 1) extensive area of encephalomalacia and gliosis, affecting the temporal lobes bilaterally, including the amygdala, the uncus, and the hippocampus, the insular lobes bilaterally, the frontobasal region, the right anterior cingulate gyrus, and the genu, trunk, and splenium of the corpus callosum; 2) areas of encephalomalacia/gliosis in the lower part of the cerebellar hemispheres; 3 ) relative preservation of the occipital lobe and of the nucleus-capsular region. In the same year, stereotactic NPD was indicated to control her aggressive behavior, respecting the protocol of the Federal Council of Medicine and with the consent of the family and of the legal guardian. Using software planning and the stereotactic technique, the NAcc, the hypothalamus, the cingulate, and the anterior limb 


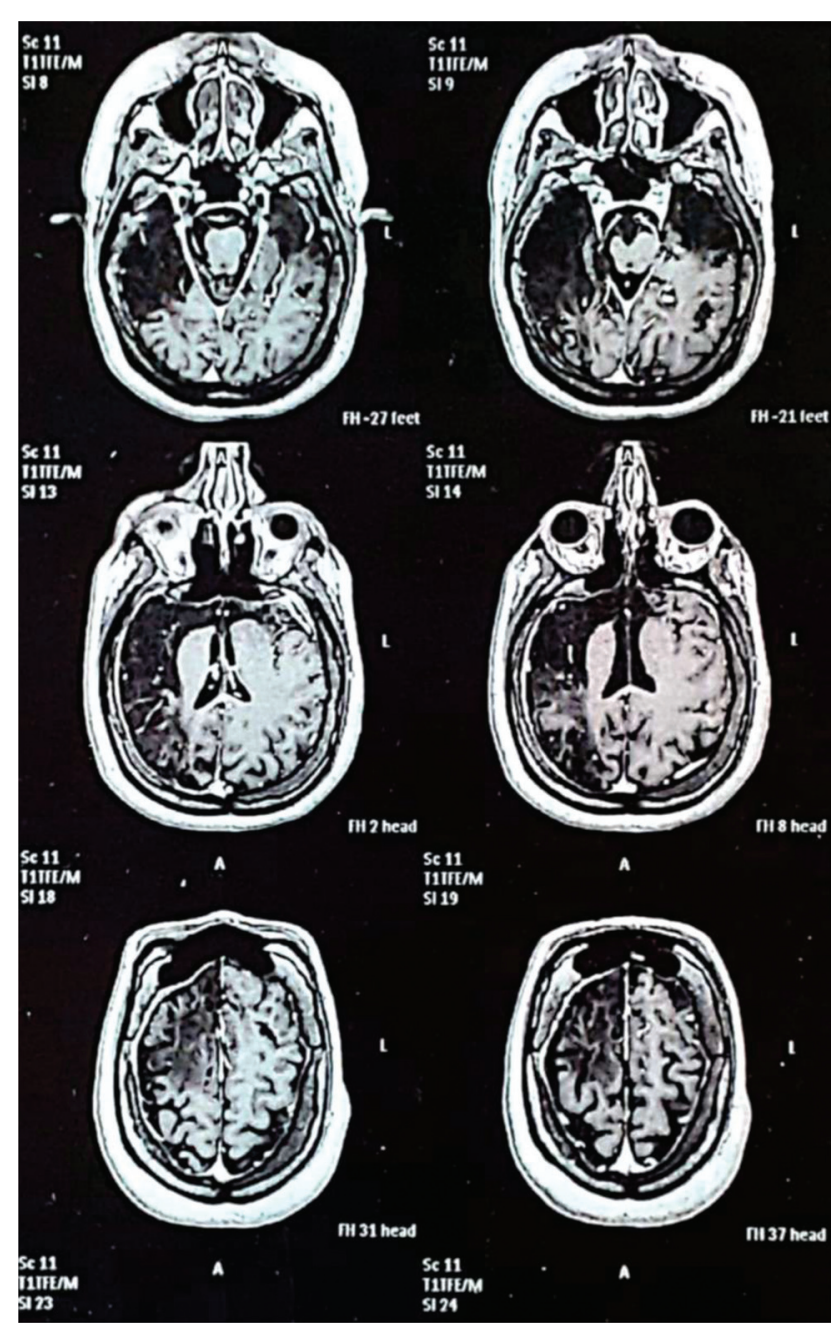

Fig. 1 Magnetic resonance imaging performed prior to the stereotactic neurosurgery for psychiatric disorder showing injuries caused by bacterial meningitis and stroke. T1 axial section: extensive area of encephalomalacia and gliosis in the right insular lobe, the genu of the corpus callosum, the temporal lobes, and the frontobasal region bilaterally, with predominance on the right; relative preservation of the occipital lobe and of the nucleus-capsular region.

of the internal capsule, all of them to the left, underwent thermocoagulation at $80^{\circ} \mathrm{C}$ for 80 seconds. The range of the NAcc coordinate values was between 5 and $6 \mathrm{~mm}$ under the line joining the anterior and posterior commissure, $17 \mathrm{~mm}$ anterior to the brain midpoint, and $5 \mathrm{~mm}$ lateral to the brain midline; the anterior cingulotomy involved lesions $20 \mathrm{~mm}$ posterior to the anterior extent of the frontal horn of the lateral ventricles, between 5 and $7 \mathrm{~mm}$ off the midline, and $5 \mathrm{~mm}$ above the corpus callosum; the lesions in the anterior capsule were performed in the middle of the anterior limb of the internal capsule, $\sim 4 \mathrm{~mm}$ above the level of the midcommissural plane. The hypothalamus was located by macrostimulation, using a 2-mm exposed tip electrode, with frequency between $5 \mathrm{~Hz}$ and $100 \mathrm{~Hz}$ and voltage ranging from $1 \mathrm{~V}$ to $10 \mathrm{~V}$. As an electrophysiological response, the patient presented autonomic signs, including mydriasis, increase in mean arterial pressure and heart rate, and ipsilateral eyeball inversion. The target point chosen was $2 \mathrm{~mm}$ laterally, $2 \mathrm{~mm}$ posteriorly, and $2 \mathrm{~mm}$ inferiorly from

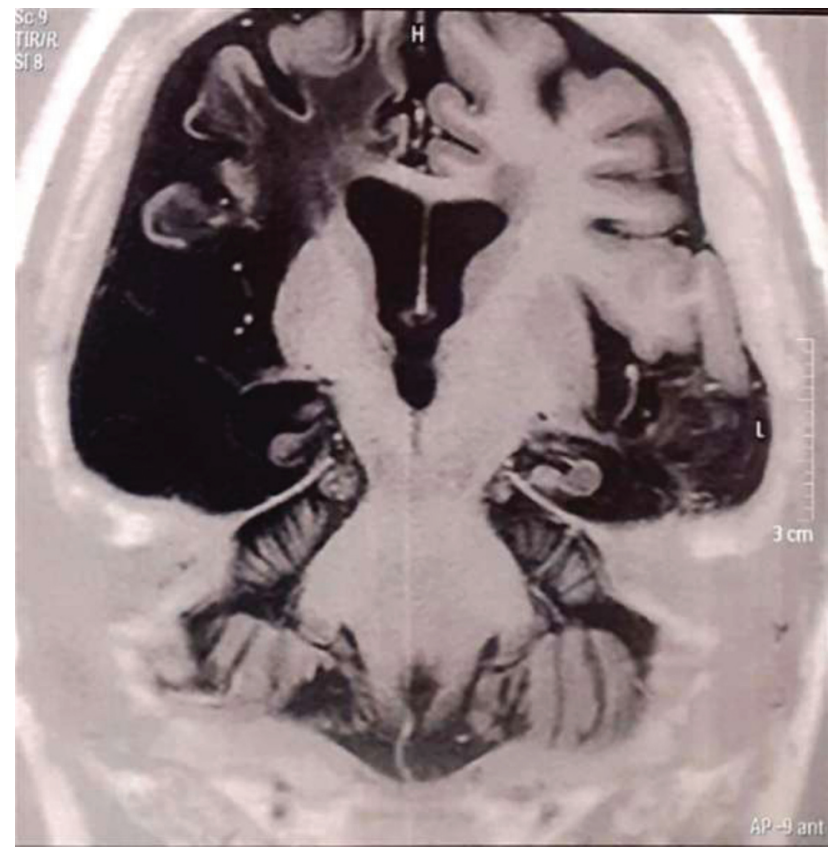

Fig. 2 Magnetic resonance imaging performed prior to the stereotactic neurosurgery for psychiatric disorder showing injuries caused by bacterial meningitis and stroke. T1 inversion recovery coronal section: encephalomalacia and gliosis affecting the right insular lobe, the right frontobasal region, and the temporal lobes bilaterally, with predominance on the right.

the midpoint of the intercommissural line. No complications occurred during the surgical procedure or in the postsurgical period.

The prescribed medication, quetiapine hemifumarate and clonazepam, was discontinued without medical advice shortly after the surgery, because the family considered that the patient had achieved a stable condition with no return of symptoms. One year after the surgery, the patient still showed no postsurgical complications, with improvement in her aggressive condition, with a decrease in verbal aggression and property damage, a partial decrease in sex drive, and absence of self-harm and heteroaggression (MOAS score 5).

The present study was approved by the Ethics Committee of the Pontifícia Universidade Católica de Goiás (CAAE: 29424920.0.0000.0037). It was conducted according to the Helsinki Declaration, and the written consent was signed by the legal guardian of the patient.

\section{Discussion}

\section{Meningitis and its Neurological Complications}

Bacterial meningitis is a group of diseases characterized by the inflammatory process of the subarachnoid space and of the leptomeningeal membranes (arachnoid and pia mater), the protective covering for the brain and the spinal cord. ${ }^{12}$ It is a serious and life-threatening condition and remains a major public health challenge. The main microorganisms involved are Streptococcus pneumoniae, Haemophilus influenzae, and Neisseria meningitidis. ${ }^{13}$ 
After invading the nasopharynx mucosa, these bacteria overcome the defense barriers of the central nervous system and penetrate the subarachnoid space, which lacks mechanisms capable of controlling bacterial replication. Pathogens release active subcapsular components such as lipopolysaccharide or peptidoglycan and teichoic acid, compounds that stimulate astrocytes and microglia cells to produce cytokines such as tumor necrosis factor and interleukin-1, which, in turn, trigger the meningeal inflammatory response, with neutrophil adhesion to endothelial cells and their passage to the subarachnoid space. ${ }^{1,14,15}$

The inflammatory response causes endothelial damage, increases the permeability of the blood-brain barrier, and allows the entry of serum proteins into the subarachnoid space, generating vasogenic edema. ${ }^{16}$ Bacteria and neutrophils release toxic substances and produce inflammatory exudates that alter cerebrospinal fluid dynamics, resulting in interstitial edema. Both forms of edema are responsible for the increase in intracranial pressure, causing a decrease in cerebral perfusion, hypoxemia, and anaerobic metabolism, which determines the consumption of glucose and hypoglycorrhachia, leading to brain damage. 1,14,17

Strokes are a particular complication of bacterial meningitis. Among the mechanisms that cause cerebral ischemia, the increase in cerebral blood flow velocity, vasculopathies, and intravascular thrombosis result from inflammation. The progression of the infection to sepsis affects the vascular selfregulation of the central nervous system, making the cerebral blood flow dependent on systemic pressure. In cases of systemic hypotension, a reduction in brain irrigation and tissue ischemia occur. ${ }^{3}$

The interaction and synergy of the events described above can cause focal or diffuse irreversible damage to the brain. It has been long believed that diffuse brain lesions result in psychic changes. $^{18}$

The patient that has a stroke in a certain cerebral hemisphere can have hemiplegia on the opposite side of the lesion due to the crossing of the motor pathways in the brainstem. ${ }^{19,20}$ Other symptoms associated with a stroke are dysphagia, hemianopsia, and urinary and fecal incontinence. The most common psychological consequences reported are anxiety, depression, as well as sleep, sexual, motor, sensory, cognitive, and communication disorders. ${ }^{21}$

\section{Brain Injury and Etiology of Behavioral Changes}

Lesions to the frontal lobe as well as to both temporal lobes can trigger aggressive behavior. The association of orbitofrontal cortex lesions with inappropriate behaviors such as impulsivity, anger, little expression of happiness, and personality disorders has been reported. ${ }^{21}$ The frontal cortex and the ventromedial frontal cortex are involved in the inhibition and control of emotions, whereas the orbitofrontal cortex plays a role in anger and pathological aggressive behavior, is directly involved in the modulation of reactive aggression, and regulates the calculation of consequences and punishments to aggressive responses. ${ }^{22,23}$

Aggressive and impulsive patients have shown decreasing activation of inhibitory regions in the left anteromedial cortex when compared with control subjects. These patients also presented deactivation of the anterior cingulate gyrus and activation of the posterior cingulate gyrus. ${ }^{22}$ The cingulate gyrus is the structure involved in evaluating the approach of stimuli capable of triggering the aggressive response. However, different patterns of brain activation can occur in individuals with an impulsive and aggressive personality. ${ }^{22,24}$

The effects caused by the lesion of the midtemporal lobe, which includes subcortical structures such as the amygdala and the hippocampus, are still controversial. The amygdala is responsible for detecting, generating, and maintaining emotions related to fear, as well as for coordinating appropriate responses to threat and danger. Thus, injuries to the amygdala in humans reduce the expression of emotions and the ability to recognize fear. Some studies have indicated that, in apes, bilateral lesions in the temporal lobe, which reach the contralateral amygdala, cause loss of fear, adoption of docile posture, extreme curiosity, quick forgetfulness, tendency to put objects in the mouth, and intense sexual impulse. ${ }^{25}$ Humans with damage to both temporal lobes (Klüver-Bucy syndrome) react in a similar way, with apathy, lethargy, emotional insensitivity, hypersexuality, psychic blindness or visual agnosia, strong oral tendencies, and hypermetamorphosis. ${ }^{25,26}$

Other studies have demonstrated a correlation between temporal lobe abnormalities, such as reduced tissue volume and/or activity, and exacerbated aggressive behavior. ${ }^{27} \mathrm{New}$ functional and structural neuroimaging techniques for examining abnormalities of the temporal lobe have revealed temporal irregularities, including asymmetric gyratory patterns in the parietal-temporal region, decreases in the volume of the anterior-inferior temporal lobe (encompassing the amygdala-hippocampus region or adjacent areas), increases in the volume of the left temporal lobe, and specific pathologies of the amygdala. ${ }^{28}$

In patients with borderline personality syndrome, the glucose metabolism is increased in the anterior cingulate, bilaterally in the upper frontal gyrus, in the lower right frontal gyrus, and in the operculum of the precentral gyrus, and is decreased in the left hippocampus and in the cuneus. The hippocampus is involved in fear responses and stressful situations, participating in the regulation of emotions. Dysfunctions in this region, therefore, can generate symptoms of anxiety and impulsivity. Glucose hypometabolism has also been found in the ipsilateral cuneus, even though the interconnections between the hippocampus and the cuneus are not fully known. ${ }^{29}$

Damage to the frontal lobe has been associated with exacerbated and targeted aggressive responses, while temporal lobe dysfunction generates bursts of misdirected anger. ${ }^{30}$ Neuropathologies that occur in both areas can increase the risk of exacerbated aggressive behavior compared with those that affect only one or the other area. ${ }^{27}$

Prefrontal and insular regions are also implicated in eating disorders such as obesity, with a gray matter volume reduction in the medial prefrontal cortex, the anterior cingulate, the frontal pole, the caudate nucleus, and the 
uncus, as well as a white matter volume decrease in the anterior limb of the internal capsule, adjacent to the caudate nucleus. These regions are involved in the decision, motivation, and reward processes, which suggests a relationship between the anatomical structures described, atypical behaviors, and polyphagia. ${ }^{31}$

The corpus callosum can be anatomically subdivided into the rostrum, the genu, the anterior body, the anterior middle body, the posterior middle body, the isthmus, and the splenium. ${ }^{32}$ Among the major psychiatric diseases associated with morphological changes in the corpus callosum are those originating from injuries to the splenium or to the posterior middle body. Splenial lesion is associated with depression, a syndrome characterized by loss of pleasure in daily activities, with cognitive and sleep alterations, loss of appetite and of sexual interest. Injury to the posterior trunk of the corpus callosum is associated with Tourette syndrome. $^{32,33}$ This chronic tic disorder is manifested by fluctuating motor and vocal tics (emission of sounds with differing degrees of intensity and frequency, or sudden, repetitive, involuntary, rapid movements, rhythmless and stereotyped, with unpredictable durations). They usually occur as attacks, are reduced by sleep, and may cause social and occupational limitations. ${ }^{33,34}$

It has been recognized that the cerebellum, in addition to its motor functions, also acts in several cognitive processes. Cerebellar damage may be associated with dysfunctions in executive tasks, learning, procedural and declarative memory, language processing, visual and spatial functions, as well as with dysfunctions in personality, affection, and cognition. ${ }^{12}$ In 1998, a new concept related to the cerebellum was created: "dysmetria of thought" or "cognitive dysmetria." According to this concept, the cerebellum would be responsible for the chronology of reasoning and of ideas, and it would be altered in several diseases such as schizophrenia, autism, dyslexia, and bipolar mood depression. ${ }^{35}$ The cerebellum has the capacity to regulate the mood via the nuclei. Emotional control is achieved through its influences on the prefrontal cortex and on the hypothalamus. Anatomically, posterior lobe injuries are associated with cognitive changes, while lesions in the cerebellar vermis are associated with affective disorders. The anterior lobe is directly involved in motor functions, showing little correlation with cognitive and affective symptoms. ${ }^{36}$

In the case reported in the present article, the synergy of the lesions found in the patient before the stereotactic NPD resulted in the behavioral changes described. This is a rare and extremely interesting case, since the patient, despite presenting with bilateral lesions of the amygdala, was not diagnosed with Klüver-Bucy Syndrome, but with an exacerbation of aggressive behavior as a complication of the stroke. Targets used in surgical procedures in the right hemisphere can lead to a functional imbalance between these behavioral structures. Thus, the treatment can be more effective using a bilateral approach and multiple targets. Other findings about this patient are consistent with the literature, showing a relationship, even if not yet completely clarified, between neuroanatomical structures and the human psyche. The role of the cerebellum in aggressive behavior cannot be ruled out in the present case, and may become a surgical target in the future, after further studies.

\section{Limbic System}

The indication of NPDs is based on scientific evidence that correlates psychiatric illnesses to the limbic system and the pathophysiology of emotions. ${ }^{37}$ Psychiatric disorders considered eligible for NPD are not yet fully understood from a pathological perspective, since injured brain areas are part of a large neuronal network, which has only been empirically defined. The smaller and more precise targets currently used in surgical procedures are the result of nearly a century of improvement in surgical techniques, neuroanatomy, neurophysiology, and neuropsychiatry. ${ }^{38}$

The term "limbic system" was first used by MacLean in $1955,{ }^{39}$ but Willis and Broca were the first ones to describe the limbic lobe, in 1664 and 1828 , respectively. ${ }^{40}$ In 1937 , Papez was a pioneer who suggested the existence of a circuit of specific brain structures responsible for human emotion. From the observation that the hypothalamus played a significant role in the expression of emotions, and that higher cognitive thoughts arose from activity in the cortical areas (frontal lobes), Papez postulated that since emotion can be influenced by thought, and thought can be influenced by emotion, the hypothalamus (emotion) would be connected with other upper cortical areas (thought). Thus, he proposed a circuit in which the cortex connects to the cingulate gyrus, which connects to the hippocampus, which in turn connects to the mammillary bodies (hypothalamus) through the fornix. The mammillary bodies project to the anterior thalamic nuclei, which connect back to the cingulate gyrus, and then to the cortical areas. He considered that the cingulate cortex is the cortical region receptive to emotional impulses. ${ }^{41}$

In 1955, MacLean ${ }^{39}$ added other structures to the limbic system, such as the septal area, the NAcc, the orbitofrontal cortex, the anterior temporal cortex, the dorsomedial thalamic nuclei, and the amygdala. Later, Goldenberg divided the limbic system into three limbic subcircuits: 1) the medial limbic circuit, including the classic Papez circuit; 2) the basolateral circuit, including the orbitofrontal cortex, the anterior temporal cortex, the amygdala, and the magnocellular division of the dorsomedial nucleus of the thalamus (frontothalamic pathway); and 3) a defense reaction circuit, including portions of the hypothalamus, the stria terminalis, and the amygdala. ${ }^{38,42}$ The circular nature of these pathways may explain why surgical injuries performed at different locations within the same circuit can alleviate the same symptoms, and why injuries in two or more circuits produce better results than isolated lesions. ${ }^{38}$ These pathways and their interactions with the basal ganglia (corticostriatothalamic pathways) constitute the anatomy of human emotion, and disturbances in these routes are considered the substrate of behavioral psychiatric illness. ${ }^{38}$

\section{Neuropsychosurgery History and Targets}

Most probably, neurosurgery began in the Antiquity era, through the practice of trepanation, a surgical removal of 
sections of the cranial vault during life, ${ }^{43}$ performed with the aid of a cylindrical instrument of varying size and shape called a trephine. ${ }^{44}$ The use of trepanation to relieve neuropsychiatric symptoms has been shown to date back to 5100 $\mathrm{BC}$; therefore, the history of psychosurgery, currently named $\mathrm{NPD},{ }^{45}$ is as old as the history of psychiatric illnesses. ${ }^{46}$

In the $19^{\text {th }}$ century, during the neuroscientific era of brain-behavior correlation, Broca and Wernicke established a clinicopathological parallelism between the neuroanatomical substrate and cognitive functions such as language. ${ }^{40}$ Influenced by these discoveries, in 1888, the Swiss psychiatrist Johann Gottlieb Burckhardt inaugurated modern psychosurgery, performing the first procedure of the modern era. He excised various brain regions from six chronic psychiatric patients under his care. As a result, three progressed successfully and one died. The difficulty in establishing a good outcome in the postoperative period led to the discredit of the technique and to the consequent abandonment of the project even before its publication, in $1891 .{ }^{47}$

In spite of this, neurosurgeons continued their investigation of ablative brain surgery: the Estonian Lodovicus Puusepp performed frontal lobotomies with relative success; ${ }^{40}$ the American-Canadian Wilder Graves Penfield obtained symptomatic psychological relief after resection of tumors, abscesses, and other brain injuries ${ }^{48}$; in 1935 , at the Second World Congress of Neurology, the American John Farquhar Fulton presented, together with the American animal psychologist Carlyle F. Jacobsen, the resection of the anterior frontal cortex with behavioral changes in apes, ${ }^{9,40}$ whereas the Portuguese António Egas Moniz proposed, for the first time, the ablation of the frontal cortex in humans with psychiatric diseases. ${ }^{40}$

In fact, Moniz was the first one to introduce the term "psychosurgery", and following the footsteps of Fulton and Jacobsen, in 1936, he and Pedro Almeida Lima performed the first neurosurgery to treat psychiatric disorders in humans, called "prefrontal lobotomy." The surgery performed by the Portuguese neurosurgeons achieved good effectiveness, but a relevant number of patients had frontal lobe syndrome as a complication (apathy, euphoria, distraction, and disinhibition), returned to nursing homes, and were no longer seen. 9,40

Between 1936 and 1949, the American neurologist Walter Jackson Freeman and neurosurgeon James W. Watts modified the technique of Moniz and Lima and developed the transorbital lobotomy. Between 1936 and 1956, 60,000 lobotomies were performed in the USA, some of them without precise indications and in poor conditions, generating a large number of complications, ranging from convulsive disorders in the postoperative period to infection and death. ${ }^{9,40}$ This surgical intervention was received with prejudice and discrimination, especially during World War II, when it was indiscriminately used in humans in the absence of a bioethical protocol. ${ }^{49}$

The development of sophisticated stereotactic target localization techniques, brain atlases, and imaging methods made stereotaxis possible. This surgical procedure is performed with a geometric orientation device fixed on the head, which directs the instrument to the coordinates of the target, increasing the precision of neurosurgery and reducing brain damage. ${ }^{5,50}$

In the 1940s, the Austrian neurologist Ernest A. Spigel and the American neurosurgeon Henry T. Wycis performed stereotactic surgery in humans using dorsomedial thalamotomy in schizophrenic patients for the first time. Their technique increased the accuracy of neurosurgery and decreased brain damage. ${ }^{51}$ Since the 1950 s, the demand for psychosurgery has significantly decreased due to the development of psychotropic drugs. ${ }^{9,40,49}$ Nonetheless, for some patients presenting with psychiatric diseases refractory to clinical treatment, the use of psychosurgery remains valid. Stereotactic surgeries are, therefore, used especially in these cases, mainly for obsessive compulsive disorder (OCD), chronic pain, and Parkinson disease, among others. ${ }^{52-54}$

Nowadays, the main targets addressed in psychosurgery for pathological aggressiveness are the hypothalamus, the amygdala, the anterior capsule, the cingulate gyrus, and the NAcc. The procedures can be neuromodulatory and ablative, used separately or together. ${ }^{55}$ The most used ablative procedures are posteromedial hypothalamotomy, amygdaloidotomy, anterior capsulotomy, anterior cingulotomy, subcaudate tractotomy, and limbic leucotomy. ${ }^{52,55}$

In 1966, bilateral lesions of the posteromedial hypothalamus resulted in a significant reduction in aggressiveness. An interval of 7 to 10 days between the completion of the 2 lesions was recommended, since severe and potentially fatal hypothalamic dysfunction was observed in cases in which they were performed simultaneously. ${ }^{56}$ This procedure is based on the hypothalamic functions, namely processing information from the external environment, controlling aggressive behavior, and ceasing the activity of the middle-basal hypothalamus (area of aggression). Therefore, posteromedial hypothalamotomy leads to reduced activation of the limbic system and, consequently, of aggressive behavior. This target has also been used in deep brain stimulation (DBS), leading to improvement in epileptic seizures. $9,51,53$

Amygdaloidotomy is performed especially by thermocoagulation. It is based on the association between the amygdala and the modulation of aggressive behavior, its connections with the prefrontal, parietal, and insular cortexes, the cingulate gyrus, the hypothalamus, and the reticular formation, and its role in controlling neuroendocrine and autonomic responses. ${ }^{9}$ A reduction in aggressive behavior has been reported as a result of bilateral lesions to the central nucleus of the amygdala. ${ }^{57,58}$ Nonetheless, this procedure has the rare complication of Klüver-Bucy syndrome. ${ }^{58}$

Anterior capsulotomy, developed by the Swedish neurosurgeon Lars Leskell and the French psychiatrist and neurosurgeon Jean Talairach in 1949, is based on the disruption of the orbitofrontal cortex and of the limbic system by targeting the fibers that connect them, located between the caudate nucleus and the putamen. This procedure has adverse effects such as mental confusion, weight gain, nocturnal enuresis, headache, and impaired memory. ${ }^{40,55}$ Although these effects rarely occur, they can last long in the postoperative period. 
This procedure has been indicated in cases of intractable OCD, with a success rate of up to $70 \%{ }^{9,53}$

Anterior cingulotomy was developed by the American neurosurgeon H. Thomas Ballantine in the early 1960s as a treatment for patients with anxiety, intractable pain, and mood disorders. ${ }^{40}$ Bilateral MRI-guided thermocoagulation is used to create ablation lesions of fibers that connect the cingulate cortex, the orbitofrontal cortex, and the limbic system. Currently, it is mainly used in the treatment of OCD. ${ }^{40,53,55}$ This procedure has a low rate of adverse effects. A study listing $>800$ cases of cingulotomy at the Massachusetts General Hospital over a 40-year period revealed no casualties and only 2 cases of infection. ${ }^{53}$

Subcaudate tractotomy, developed by the British neurosurgeon Geoffrey Knight in 1964, is the interruption of the fibers that connect the orbitofrontal cortex to the subcortical limbic structures through the ablation of the innominate substance in the area inferior to the head of the caudate nucleus. ${ }^{53}$ Since 1970, the Brook General Hospital in London has reported $>1,300$ cases of subcaudate tractotomy performed in patients with affective disorders such as OCD and chronic anxiety. An improvement has been observed in between 40 and $60 \%$ of the patients 1 year after the procedure. ${ }^{59}$ Complications are usually induced edema, transient postoperative disorientation, and long-term seizures. , $^{9,53,55}$

Limbic leucotomy, introduced by Desmond Kelly and Nita Mitchell-Heggs in England in 1973, is a combination of bilateral cingulotomy and subcaudate tractotomy ${ }^{40}$ that causes the interruption of the Papez circuit by disconnecting the frontolimbic and the corpus callosum. The lesion is made on the lower side of the head of the caudate nucleus and on the anterior cingulate gyrus, and also involves the mid-lower quadrant of the frontal lobe. ${ }^{55}$ In the first 24 to 48 hours after surgery, patients may experience confusion and drowsiness, with subsequent recovery. ${ }^{53}$

Since the NAcc plays a role in immediate reward circuits and also in modulating repulsive stimuli, it has also been proposed as a target to control aggressive behavior. ${ }^{60}$ Its stimulation is effective to control addiction to drugs, nicotine, and alcohol, as well as to reduce aggressive behavior in patients with $O C D$, Tourette syndrome, and pathological obesity. ${ }^{61}$

All the multiple targets described can be used, isolated or in combinations, in NPDs, depending on the psychiatric illness and on the experience of the neurosurgeon. ${ }^{10} \mathrm{~A} 27$ year-old male patient diagnosed with organic delusional disorder, absence epilepsy, and pathological aggressiveness underwent NPD using the stereotactic technique, combining left medial hypothalamotomy and bilateral anterior capsulotomy. Although schizophrenia and epilepsy remained unchanged, the patient had important improvement in his aggressive behavior immediately after the procedure. ${ }^{9}$

A 14-year-old and a 16-year-old male patient, both diagnosed with severe pathological aggressiveness refractory to clinical pharmacological treatment, were operated on using the multitarget stereotactic technique. In the former, four interventions were performed with 3-month intervals between the procedures: 1) left posteromedial hypothalamotomy; 2) anterior capsulotomy; 3 ) right post- eromedial hypothalamotomy and bilateral reinforcement of the lesion to the anterior limb of the internal capsule; 4) NAcc lesion. In the latter, 2 procedures were performed: left posteromedial hypothalamotomy and, after 1 year, right posteromedial hypothalamotomy associated with anterior capsulotomy. Both patients experienced significant improvement in symptoms and no recurrence of aggressive behavior. ${ }^{60}$

Bilateral anterior capsulotomy was performed in 13 patients with epilepsy and psychiatric comorbidities such as psychotic symptoms, pathological aggressiveness, impulsivity, anxiety, depression, and intellectual disability. The neurosurgical procedure was considered an effective treatment for epileptic patients presenting with refractory psychotic symptoms and aggressive behavior. It also improved the compliance of the patients with antiepileptic medication regimens. The most common but transient side effects of this surgery were fatigue and laziness. ${ }^{62}$

The combination of anterior cingulotomy and anterior capsulotomy was employed for the treatment of pathological aggressiveness in 10 patients, who showed improvement in their condition and reintegration into society. A total of 13 adverse effects related to the surgical procedure were reported, but all complications were temporary. ${ }^{63}$

Additionally, the combination of NAcc DBS with anterior capsulotomy is an effective treatment for drug addiction. A 28-year-old male patient who had a polysubstance use disorder (bucinnazine, morphine, and hypnotics) for 13 years, severe depression, and anxiety underwent a combination of bilateral NAcc DBS with bilateral anterior capsulotomy. After the procedure, he had an evident decrease in his craving for the three drugs. Furthermore, he showed significant improvements in depression, anxiety, sleep, quality of life, and most aspects of cognitive functioning. ${ }^{64}$

In the case reported in the present article, the patient underwent multitarget stereotactic surgery to control chronic pathological aggressiveness refractory to clinical treatment. The targets were selected based on the clinical manifestations of the patient. The procedure was uneventful and resulted in a decrease in the aggressive behavior and in a partial decrease in sexual impulse, leading to improvement in the quality of life of the patient and her family. The patient also showed improvement in the symptoms of binge eating disorder, with reduced searches for food. Our outcomes corroborate the findings that lesions to the NAcc address behaviors associated with vandalism and irritability, ${ }^{10}$ and also confirm its role in compulsive behavior, which may be connected with binge eating disorder. ${ }^{61}$

\section{Conclusion}

The reported case and several publications bring to light the discussion of refractory aggressiveness therapy, a complex scenario, and show that multitarget stereotactic NPD, wellperformed in properly selected patients, is capable of producing satisfactory results, controlling symptoms, and 
improving quality of life. However, it is clear that further studies on the correspondence between brain injuries and symptoms are still needed, since no formal consensus has been reached on the targets that should be used in each case.

Scientific knowledge is still limited to fully understand the pathophysiology of pathological aggressiveness of the patient in the present case, who had brain injuries caused by bacterial meningitis and stroke that resulted in lesions to targets normally used in NPD for aggressiveness, leading to aggressive behavior. Interestingly, the destruction of these structures in the ablation procedure causes significant improvements in pathological aggressiveness. This finding highlights the broad variations in the clinical repercussions reported after NPD for pathological aggressiveness.

\section{Conflict of Interests}

The authors have no conflict of interests to declare.

\section{References}

1 Faria SM, Farhat CK. Meningites bacterianas - diagnóstico e conduta. J Pediatr 1999;75(Suppl 1):S46-S56

2 Brasil Ministério da Saúde. DATASUS. Meningite - casos confirmados notificados no sistema de informação de agravos de notificação - Brasil, 2019. Brasília, DF: Ministério da Saúde; 2019. Access in: September 24, 2020 at: http://tabnet.datasus. gov.br/cgi/tabcgi.exe?sinannet/cnv/meninbr.def

3 Siegel JL. Acute bacterial meningitis and stroke. Neurol Neurochir Pol 2019;53(04):242-250

4 Brasil Ministério da Saúde. Secretaria de Vigilância em Saúde. Departamento de Vigilância Epidemiológica. Guia de vigilância epidemiológica. 7th ed. Brasília, DF: Ministério da Saúde; 2009

5 Faria MA. Violence, mental illness, and the brain - A brief history of psychosurgery: Part 3 - From deep brain stimulation to amygdalotomy for violent behavior, seizures, and pathological aggression in humans. Surg Neurol Int 2013;4:91

6 Yudofsky SC, Silver JM, Jackson W, Endicott J, Williams D. The Overt Aggression Scale for the objective rating of verbal and physical aggression. Am J Psychiatry 1986;143(01):35-39

7 Edlinger $M$, Welte AS, Yalcin-Siedentopf $N$, et al. Trends in pharmacological emergency treatment of patients suffering from schizophrenia over a 16-year observation period. Int Clin Psychopharmacol 2018;33(04):197-203

8 Hollander E, Kwon JH, Stein DJ, Broatch J, Rowland CT, Himelein CA. Obsessive-compulsive and spectrum disorders: overview and quality of life issues. J Clin Psychiatry 1996;57(Suppl 8):3-6

9 Santos RG, Mengai ACS, Silva LJ, Arruda JB. Tratamento cirúrgico da agressividade: relato de caso. J Braz Neurosurg 2014;25(04): 367-372

10 Wang W, Li P. Surgical management for aggressive behavior. In: Sun B, Salles A, editors. Neurosurgical treatments for psychiatric disorders. Dordrecht: Springer; 2015:203-209

11 Kay SR, Wolkenfeld F, Murrill LM. Profiles of aggression among psychiatric patients. I. Nature and prevalence. J Nerv Ment Dis 1988;176(09):539-546

12 Feigin RD. Bacterial meningitis beyond the neonatal period. In: Feigin RD, Cherry JD, editors. Textbook of pediatric infectious diseases. Philadelphia: WB Saunders; 1998:400-429

13 World Health Organization. Meningitis. Geneva: WHO; 2020 Access in: September 24, 2020 at: https://www.who.int/healthtopics/meningitis\#tab=tab_1

14 Quagliarello V, Scheld WM. Bacterial meningitis: pathogenesis, pathophysiology, and progress. N Engl J Med 1992;327(12): 864-872
15 Tunkel AR, Wispelwey B, Scheld WM. Pathogenesis and pathophysiology of meningitis. Infect Dis Clin North Am 1990;4(04): 555-581

16 Sztajnbok DCN. Meningite bacteriana aguda. Rev Pediatr SOPERJ 2012;13(02):72-76

17 Sáez-Llorens X, Ramilo O, Mustafa MM, Mertsola J, McCracken GH Jr. Molecular pathophysiology of bacterial meningitis: current concepts and therapeutic implications. J Pediatr 1990;116(05): 671-684

18 Pires N. Sändromes mentais e doencas cerebrais. Arq Neuropsiquiatr 1953;11(01):41-52

19 Hood GC, Dincher JR. Fundamentos e prática de enfermagem: atendimento completo do paciente. 8th ed. Porto Alegre: Artes Médicas; 1995

20 Schäfer PS, Oliveira-Menegotto L, Tisser L. Acidente vascular cerebral: as repercussões psíquicas a partir de um relato de caso. Ciênc Cogn 2010;15(02):202-215

21 Rocha FL, Cunha UGV, Giacomin KC. Depressão pós-acidente vascular cerebral (AVC). J Bras Psiquiatr 1993;42(04):203-208

22 New AS, Hazlett EA, Buchsbaum MS, et al. Blunted prefrontal cortical 18fluorodeoxyglucose positron emission tomography response to meta-chlorophenylpiperazine in impulsive aggression. Arch Gen Psychiatry 2002;59(07):621-629

23 Blair RJR. The roles of orbital frontal cortex in the modulation of antisocial behavior. Brain Cogn 2004;55(01):198-208

24 Siever LJ. Neurobiology of aggression and violence. Am J Psychiatry 2008;165(04):429-442

25 Esperidião-Antonio V, Majeski-Colombo M, Toledo-Monteverde D, et al. Neurobiologia das emoções. Rev Psiquiatr Clin (Santiago) 2008;35(02):55-65

26 Lippe S, Gonin-Flambois C, Jambaqué I The neuropsychology of the Klüver-Bucy syndrome in children. Handb Clin Neurol 2013; 112:1285-1288

27 Potegal M. Temporal and frontal lobe initiation and regulation of the top-down escalation of anger and aggression. Behav Brain Res 2012;231(02):386-395

28 Bufkin JL, Luttrell VR. Neuroimaging studies of aggressive and violent behavior: current findings and implications for criminology and criminal justice. Trauma Violence Abuse 2005;6(02):176-191

29 Juengling FD, Schmahl C, Hesslinger B, et al. Positron emission tomography in female patients with borderline personality disorder. J Psychiatr Res 2003;37(02):109-115

30 Golden CJ, Jackson ML, Peterson-Rohne A, Gontkovsky ST. Neuropsychological correlates of violence and aggression: A review of the clinical literature. Aggress Violent Behav 1996;1(01):3-25

31 Kennedy JT, Astafiev SV, Golosheykin S, Korucuoglu O, Anokhin AP. Shared genetic influences on adolescent body mass index and brain structure: A voxel-based morphometry study in twins. Neuroimage 2019;199:261-272

32 Zicarelli CAM, Georgeto SM, Fernandes KBP, Gariba MA, Dias CH, Aguiar LR. Síndromes do corpo caloso. J Braz Neurosurg 2014;25 (02):121-126

33 Felling RJ, Singer HS. Neurobiology of tourette syndrome: current status and need for further investigation. J Neurosci 2011;31(35): 12387-12395

34 Mármora CHC, Machado CCS, Delgado FEF, Loures LF, Mourão Júnior CA. Atualizações neurocientíficas na síndrome de Tourette: uma revisão integrativa. Ciênc Cogn 2016;21(02):242-254

35 Damiani D, Gonçalves VP, Kuhl L, Aloi P, Nascimento AM. Aspectos neurofuncionais do cerebelo: o fim de um dogma. Arq Bras Neurocir 2016;35(01):39-44

36 Schmahmann JD, Smith EE, Eichler FS, Filley CM. Cerebral white matter: neuroanatomy, clinical neurology, and neurobehavioral correlates. Ann N Y Acad Sci 2008;1142(01):266-309

37 Hernández P, Orrego M, Prinzo H, Martínez F, Medina C, Pollo E. Tratamiento neuroquirúrgico de la agresividad irreductible: hipotalamotomía posteromedial estereotáxica. Rev Méd Urug 2007;23 (02):126-133 
38 Feldman RP, Alterman RL, Goodrich JT. Contemporary psychosurgery and a look to the future. J Neurosurg 2001;95(06):944-956

39 MacLean PD. The limbic system ("visceral brain") and emotional behavior. AMA Arch Neurol Psychiatry 1955;73(02):130-134

40 Mashour GA, Walker EE, Martuza RL. Psychosurgery: past, present, and future. Brain Res Brain Res Rev 2005;48(03):409-419

41 Papez JW. A proposed mechanism of emotion. Arch Neurol Psychiatry 1937;38(04):725-743

42 Mega MS, Cummings JL, Salloway S, Malloy P. The limbic system: an anatomic, phylogenetic, and clinical perspective. J Neuropsychiatry Clin Neurosci 1997;9(03):315-330

43 Alt KW, Jeunesse C, Buitrago-Téllez CH, Wächter R, Boës E, Pichler SL. Evidence for stone age cranial surgery. Nature 1997;387(6631):360

44 Trejo-Ayala RA, Luna-Pérez M, Gutiérrez-Romero M, CollazoJaloma J, Cedillo-Pérez MC, Ramos-Peñafiela CO. Bone marrow aspiration and biopsy. Technique and considerations. Rev Med Hosp Gen Mex 2015;78(04):196-201

45 Nuttin B, Wu H, Mayberg H, et al. Consensus on guidelines for stereotactic neurosurgery for psychiatric disorders. J Neurol Neurosurg Psychiatry 2014;85(09):1003-1008

46 Baer L, Rauch SL, Ballantine HT Jr, et al. Cingulotomy for intractable obsessive-compulsive disorder. Prospective long-term followup of 18 patients. Arch Gen Psychiatry 1995;52(05):384-392

47 Joanette Y, Stemmer B, Assal G, Whitaker H. From theory to practice: the unconventional contribution of Gottlieb Burckhardt to psychosurgery. Brain Lang 1993;45(04):572-587

48 Hebb DO, Penfield W. Human behavior after extensive bilateral removal from the frontal lobes. Arch Neurol Psychiatry 1940;44 (02):421-438

49 Faria MAJr. Violence, mental illness, and the brain - A brief history of psychosurgery: Part 1 - From trephination to lobotomy. Surg Neurol Int 2013;4(01):49

50 Gusmão SS. Determinação das coordenadas na tomografia computadorizada estereotáxica: simplificação do método convencional. Arq Neuropsiquiatr 2002;60(3-B):775-778

51 Sano K, Mayanagi Y, Sekino H, Ogashiwa M, Ishijima B. Results of stimulation and destruction of the posterior hypothalamus in man. J Neurosurg 1970;33(06):689-707

52 Gusmão SS, Silveira RL, Arantes A. Estereotaxia: evolução, princípios, técnica e indicações. J Bras Neurocirurg 1998;9(02):56-63
53 Franzini A, Messina G, Cordella R, Marras C, Broggi G. Deep brain stimulation of the posteromedial hypothalamus: indications, long-term results, and neurophysiological considerations. Neurosurg Focus 2010;29(02):E13

54 Zhu R, Zhang Y, Wang T, et al. Deep brain stimulation of nucleus accumbens with anterior capsulotomy for drug addiction: A case report. Stereotact Funct Neurosurg 2020;98(05):345-349

55 Faria MA Jr. Violence, mental illness, and the brain - A brief history of psychosurgery: Part 2 - From the limbic system and cingulotomy to deep brain stimulation. Surg Neurol Int 2013; 4:75

56 Patel SR, Aronson JP, Sheth SA, Eskandar EN. Lesion procedures in psychiatric neurosurgery. World Neurosurg 2013;80(3-4):31. e9-31.e16

57 Sano K, Yoshioka M, Ogashiwa M, Ishijima B, Ohye C. Posteromedial hypothalamotomy in the treatment of aggressive behaviors. Confin Neurol 1966;27(01):164-167

58 Ramamurthi B. Stereotactic operation in behaviour disorders. Amygdalotomy and hypothalamotomy. Acta Neurochir Suppl (Wien) 1988;44:152-157

59 Narabayashi $\mathrm{H}$, Uno $\mathrm{M}$. Long range results of stereotaxic amygdalotomy for behavior disorders. Confin Neurol 1966;27(01): 168-171

60 Bridges PK, Bartlett JR, Hale AS, Poynton AM, Malizia AL, Hodgkiss AD. Psychosurgery: stereotactic subcaudate tractomy. An indispensable treatment. Br J Psychiatry 1994;165(05):599-611, discussion 612-613

61 Borges TJB, D’Assunção APA, Silva LJ, Oliveira LAG, Araújo PH. A importância de múltiplos alvos no tratamento cirúrgico da agressividade refratária. Rev Med Saúde Brasília 2017;6(02):193-202

62 Harat M, Rudaś M, Zieliński P, Birska J, Sokal P. Deep brain stimulation in pathological aggression. Stereotact Funct Neurosurg 2015;93(05):310-315

63 Huang P, Zheng-Dao D, Sun BM, et al. Bilateral anterior capsulotomy enhances medication compliance in patients with epilepsy and psychiatric comorbidities. CNS Neurosci Ther 2019;25(08): 824-831

64 Jiménez F, Soto JE, Velasco F, et al. Bilateral cingulotomy and anterior capsulotomy applied to patients with aggressiveness. Stereotact Funct Neurosurg 2012;90(03):151-160 